\title{
THE BRITISH SPECIES OF LUTRARIA (LAMELLI- BRANCHIA), WITH A DESCRIPTION OF L. ANGUSTIOR PHILIPPI
}

\author{
By N. A. Holme \\ The Plymouth Laboratory
}

(Plates I and II, and Text-figs. I-4)

The Lutrariidae are large lamellibranchs which burrow deeply in bottomdeposits on the shore and in shallow water. The foot is relatively weak, and they live permanently buried $30 \mathrm{~cm}$ or so beneath the surface, maintaining connexion with the overlying water through their long siphons, which are united in a common sheath for practically their whole length. The commonest British species, Lutraria lutraria (L.) is found at low-water mark on shores of muddy sand, and offshore its siphons are sometimes taken by the dredge or grab. Another species, L. magna (da Costa) is more local, and appears to inhabit muddy deposits near the mouths of estuaries. It is a southern form, being occasionally found on the south and west coasts of the British Isles, and, like $L$. lutraria, its range extends southward to the Mediterranean.

Examination of shells from offshore shell-gravel deposits near Plymouth has revealed the presence of a third form, which appears to correspond with the L. elliptica var. angustior of Philippi (1844), a variety subsequently noted by several other authors under different names. Although a distinct form, it has never been assigned specific rank, perhaps because many of the specimens found would have been dead shells washed up on the beach, in which the hinge-teeth, an important character for identification, are usually worn or broken. This form was taken by Ford (1923, 1925) at Plymouth, but was identified as L. magna, and I have also collected specimens from off other parts of the south coast of England (see Appendix for list of localities).

\section{LUTRARIA ANGUSTIOR PHILIPPI}

? Mactra lutraria variety. Turton, I819, p. 85 .

Lutraria elliptica (form). Brown, 1827, plate xii, fig. 3 .

Lutraria elliptica (form). Brown, I844, plate xliii, fig. 3 .

Lutraria elliptica var. angustior Philippi, I844.

Lutraria elliptica var. intermedia Sowerby, 1859, plate iv, fig. I, nec. fig. 2.

Lutraria elliptica var. alterutra Jeffreys, I863.

Lutraria elliptica var. angustior Philippi. Hidalgo, 1870, plate 6, fig. 2.

Lutraria elliptica var. attenuata Monterosato, I878.

Lutraria lutraria var. angustior Philippi. Bucquoy et al. 1896. 
A form of L. lutraria with a shell narrower than the type has been noted by a number of authors, but where the description is brief or unaccompanied by an illustration, some doubt must remain as to the identity of the specimen. Descriptions in the literature do not indicate that the hinge-teeth or pallial scar are different from those of typical L. lutraria, so that identity with the form here described is based solely on the shape and proportions of the valves. The first illustrations of $L$. angustior are in Brown (1827, I844), while those of Sowerby (I859), Hidalgo (I870), and especially Bucquoy et al. (I896) are also of the same species. The description, unaccompanied by a figure, by Jeffreys (I863) of var. alterutra corresponds with that of L. angustior, but although he mentions Philippi's record of $L$. lutraria from Sicily he evidently does not regard the variety as synonymous with Philippi's var. angustior. Philippi's description is brief, giving dimensions of the shell, and the opinion that it is intermediate between L. lutraria and L. magna.

Philippi's original specimens are apparently no longer in existence, but his opinion that it is intermediate between the two other species strongly suggests that it is the species described here. Bucquoy et al. (1896) give the most detailed description, accompanied by photographs, of L. lutraria var. angustior, based on specimens from the French Mediterranean coast, but unfortunately do not illustrate or describe characters on the inside of the shell. These authors considered that the variety they describe corresponds not only with Philippi's description but with that of specimens from British waters described by Brown, Sowerby and Jeffreys. This lends additional support to the use of Philippi's name angustior for the British specimens described here.

\section{Shell}

The shell is equivalve, and of an oval-elongate shape, the specimen shown in Pl. I, figs 2 and 3, measuring II $\mathrm{cm}$ long $\times 5.9 \mathrm{~cm}$ high. The ventral and posterior dorsal margins are moderately straight and parallel with one another. The posterior end is fairly evenly rounded, but the anterior end is usually more sharply curved towards the dorsal side (Fig. I B). The valves gape slightly in front, and more so posteriorly, but the arrangement of the hinge in all members of the genus is such that the valves can rock longitudinally about the hinge cartilage, so that the relative gape at either end can be varied. The shell is moderately thick, and is marked on the outside with concentric striae corresponding to the lines of growth. The periostracum on the smallest specimens is colourless and transparent, on larger specimens it is brown and slightly glossy, but on all the adults examined it was totally abraded, exposing the white prismatic layer. The beaks are not very acute, and are scarcely directed forward. They are situated about two-fifths of the shell's length from its anterior end. The ligament, as in the other species, is small and mainly internal. There is no lunule and the escutcheon is virtually absent, as in the other species. 
The inside of the shell is white and slightly glossy, with well-marked muscle scars and pallial line. There is a deep $U$-shaped pallial sinus which extends slightly forward of the mid-point of the length of the shell. The scar marking the lower edge of the sinus runs almost parallel and close to the ventral pallial scar for the greater part of its length, the two usually merging for a part of the length of the sinus. The range of variation of this character is between that shown in Fig. I B and that in Pl. I. The distal end is usually marked by an oval enlargement of the scar. The hinge plate is fairly flat, and bears a triangular pit to accommodate the large cartilage. The posterior dorsal edge of this pit is almost straight, and makes an angle of about $15^{\circ}$ with the adjacent dorsal margin of the shell. Each valve bears two erect cardinal teeth. In the right valve these are both laminar and diverge from one another at rather less than a right angle. The first tooth curves downwards so that distally it makes an angle of $60-80^{\circ}$ to the second tooth. The first tooth consists of two imbricating teeth, one lying beyond the other, and both point in the same direction. In a worn shell they may appear as a single tooth. Behind the cartilage is a low lateral tooth set in an oval-elongate depression. There is no anterior lateral tooth. The inner dorsal margins of the shell are not grooved, as in
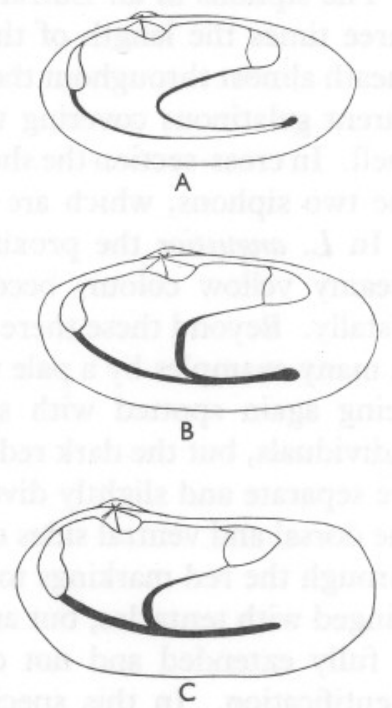

Fig. I. Interior of the right valve of Lutraria shells, showing muscle and pallial scars. A, L. lutraria; B, L. angustior; C, L. magna.

L. lutraria, and the dorsal surfaces tend to curve inwards so that the outer, striated, surface is visible in a lateral view of the interior (Fig. 2B).

The two cardinal teeth in the left valve engage between the cardinals of the right valve; the first is slightly convex on its outer side, the second straight. On their inner sides the teeth are thickened, and they are fused together for about a third of their lengths. There is a thin tongue-shaped tooth at the side of the cartilage pit, behind the second cardinal tooth. It is present in all three species (see P1. II), but is broken off in the majority of dead shells collected. Behind the cartilage pit is a low lateral tooth, as in the right valve, and there is a curved anterior lateral tooth running almost parallel with and outside the first cardinal tooth. Both lateral teeth are set in shallow depressions, but the remainder of the inner dorsal margin is convex. 


\section{Siphons}

This description is based on a single whole adult specimen, and on a number of siphons cut off by the dredge. Since the siphons are all that may be captured on offshore grounds, the differences between those of the three species are of some importance for identification.

The siphons of all Lutrarias are very long, and can be extended to two or three times the length of the shell. The two tubes are united in a common sheath almost throughout their lengths, the sheath being invested with a transparent gelatinous covering which is an extension of the periostracum of the shell. In cross-section the sheath is oval with a slight groove or 'waist' between the two siphons, which are of about the same cross-sectional dimensions.

In $L$. angustior the proximal four-fifths or so of the sheath is a uniform creamy yellow colour, becoming marked with small strawberry-red spots distally. Beyond these there is a circular band of a uniform dark red, followed in many examples by a pale whitish band, the extreme tips of the two siphons being again spotted with strawberry red. The colour pattern varies with individuals, but the dark red band is present in all examples. The two siphons are separate and slightly diverging at their tips (Fig. 3 B and Pl. I), and along the dorsal and ventral sides of the common sheath there is a pale line running through the red markings to the tip of each siphon. The siphon openings are fringed with tentacles, but as these are only to be seen when the living animal is fully extended and not disturbed in any way, they are of little use for identification. In this species the dorsal siphon is fringed with numerous small tentacles, while the ventral siphon has eight (or perhaps nine) longer tentacles. There are probably small tentacles between the longer tentacles, as in L. lutraria, but these were not distinguished. In L. lutraria there are two circles of smaller tentacles outside the opening of the ventral siphon. These were not observed in the living specimen of L. angustior, but it cannot be said with certainty that they are absent in this species.

\section{Shell}

LUTRARIA LUTRARIA (L.)

The shell grows a little larger than in the previous species, a fairly large specimen measuring $13 \mathrm{~cm}$. long $\times 7.2 \mathrm{~cm}$. in height. The dorsal margins are more convex and the anterior end more evenly rounded, so that the outline is more nearly elliptical (Fig. IA). Some specimens, however, have shell proportions similar to those of L. angustior. The valves gape to about the same extent as in that species. The shell substance is a little thinner, and the outside rather smoother. The periostracum in all but the smallest shells is an olive-brown colour, glossy, and in addition to the concentric lines of growth, is marked towards the umbo with faint radial lines, which are of use in identifying small specimens (p. 564). The beaks are more acute than 
in L. angustior, and are situated at about the same position relative to the shell's length.

The pallial scar differs from that of L. angustior. The scar marking the lower edge of the sinus meets the ventral pallial scar in a narrow V, the two remaining well separated until they meet at the posterior end of the sinus (Fig. I A). At this point the scar tends to be expanded as in L. angustior. Even in narrow shells having similar proportions to L. angustior the two scars remain well separated.
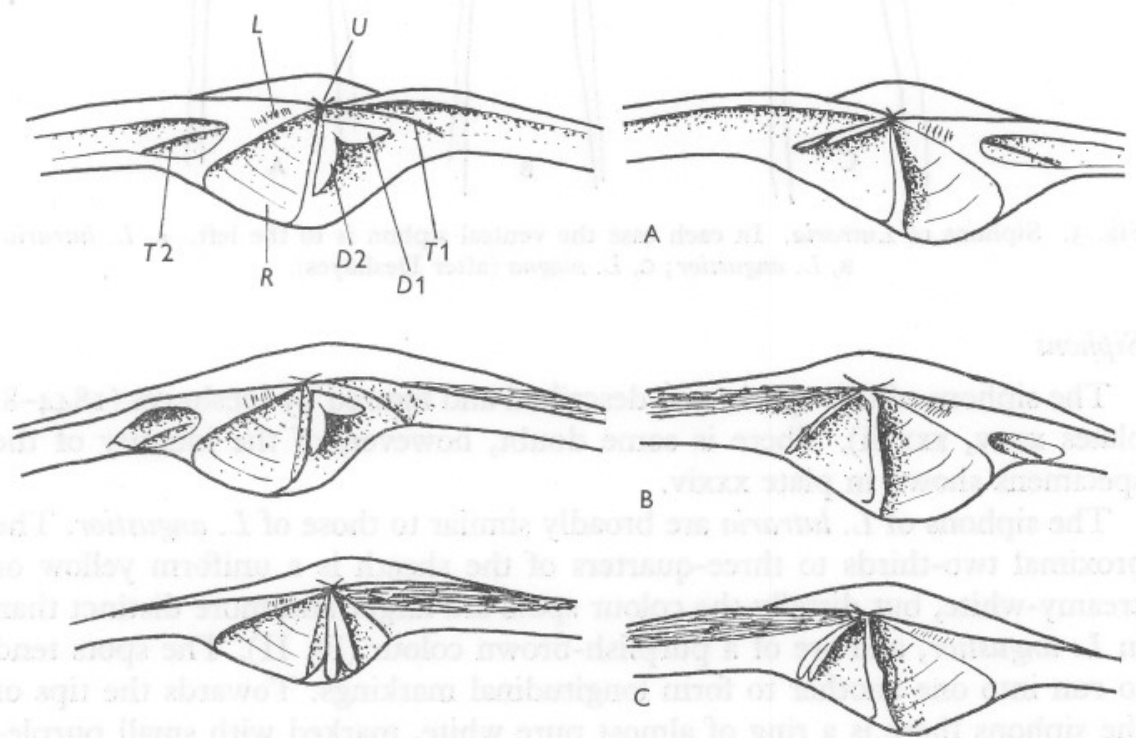

Fig. 2. Hinges of the left and right valves of Lutraria shells. The linguiform tooth between the second cardinal tooth and the cartilage in the left valve has been omitted in each case as it is so frequently broken off. $D_{1}, D_{2}$, Ist and 2 nd cardinal tooth; $T 1, T 2$, Ist and 2 nd lateral teeth; $L$, ligament attachment area; $R$, cartilage pit; $U$, umbo. Note that in no case is a pair of valves from a single specimen drawn, so that the left and right valves drawn do not exactly correspond. A, L. lutraria; B, L. angustior; c, L. magna.

The hinge (Fig. 2A) differs only in detail from the preceding species. The posterior dorsal outline of the cartilage pit is straight or slightly convex, and makes a greater angle (about $30^{\circ}$ ) with the adjacent dorsal margin of the shell. In the right valve the two cardinal teeth are straight and diverge at $80^{\circ}-90^{\circ}$. The first tooth is made up of two imbricating teeth in line, as in L. angustior. There is a low posterior lateral tooth, but the depression in which it is set is continued posteriorly as a shallow rounded groove inside the dorsal margin of the shell. A similar but rather deeper groove runs forwards from the umbo, passing dorsally to the first cardinal tooth. The dorsal edges of the shell are produced upwards and inwards in this species, so accentuating the depth of these grooves. 
In the left valve the two cardinal teeth diverge at a slightly greater angle than in L. angustior, and the first tooth is straight on its dorsal side. There is a low anterior and posterior lateral tooth, and the inner dorsal margin of the shell is grooved, as in the right valve.
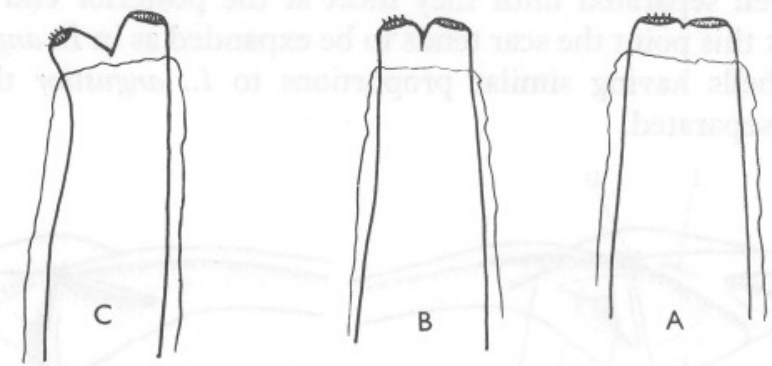

Fig. 3. Siphons of Lutraria. In each case the ventral siphon is to the left. A, L. lutraria; B, L. angustior; c, L. magna (after Deshayes).

\section{Siphons}

The siphons of this species are described and figured by Deshayes (I844-8, plates $x x x v, x x x v i i)$. There is some doubt, however, of the identity of the specimens shown in plate xxxiv.

The siphons of $L$. lutraria are broadly similar to those of L. angustior. The proximal two-thirds to three-quarters of the sheath is a uniform yellow or creamy-white, but distally the colour spots are larger and more distinct than in L. angustior, and are of a purplish-brown colour (P1. II). The spots tend to run into one another to form longitudinal markings. Towards the tips of the siphons there is a ring of almost pure white, marked with small purplebrown spots, and the pale lines along the dorsal and ventral sides of the sheath are very distinct. The siphons are scarcely separated, and do not diverge, at their tips (Fig. 3A). The form of the tentacles at the tips of the siphons is described by Deshayes.

\section{Shell}

\section{LUTRARIA MAGNA (DA COSTA)}

The shell is more elongate than in the other species, a fairly large specimen measuring $12 \mathrm{~cm}$. long $\times 5.2 \mathrm{~cm}$. high. The umbo lies rather far forward, being about one-quarter of the shell's length from the anterior end (Fig. I C). The ventral edge is fairly evenly curved, and the dorsal edge behind the umbo is curved upwards to about the same extent, so that the posterior dorsal outline is concave. The anterior end is evenly rounded, but the posterior is obliquely truncate. The posterior gape is much wider than in the other species. The valves are moderately thick, and are covered by a dark brown periostracum. The outer surface is rather irregular, and is marked with concentric growth lines. An indefinite line from the umbo to the ventral side of the truncated 
posterior divides the surface into a smoother anterior and a more wrinkled and irregular posterior part. The beaks are rather obtuse, and are directed if anything slightly forward.

There is deep $U$-shaped pallial sinus, the scar marking the lower edge of the sinus merging completely with the ventral pallial scar for practically the whole length of the sinus (Fig. I C). The distal end of the scar is not enlarged as in the other species.

The posterior dorsal outline of the cartilage pit is straight or slightly concave, and lies at a small angle $\left(\mathrm{ca} . \mathrm{IO}^{\circ}\right)$ to the adjacent dorsal edge of the shell. In the right valve the first cardinal tooth is cloven longitudinally into two subequal halves (Fig. 2C). It is therefore totally different from the corresponding tooth in the other two species. The first cardinal tooth curves downward so that the axis of its more distal part lies at only $30-40^{\circ}$ to the second tooth, which is laminar, as in the other species. In both valves the anterior part of the cartilage pit is more deeply excavated than the remainder. Posterior lateral teeth are absent in both valves, and the inner dorsal surfaces are flat or convex. In front of the umbo in both valves the striated outer surface is curved inward to an even greater degree than in L. angustior, so that it practically merges with the inner dorsal surface of the shell. In the left valve the two cardinal teeth are almost straight on their outer surfaces, and diverge at $30-40^{\circ}$. Their inner surfaces are fused together for about two-thirds of their length. There is a low anterior lateral tooth, as in the other species.

\section{Siphons}

These are described by Deshayes (I844-8, plate xxxvii), and I have not myself seen any specimens. The sheath is white proximally, becoming a shade of purple posteriorly, which gradually increases in intensity towards the tips of the siphons, often terminating in a very deep reddish-purple colour. Coloration is uniform, and there are no colour spots as in the other species, and the pale lines along the dorsal and ventral edges of the sheath are absent. The two siphons are separated at some little distance from their tips, and diverge from one another at almost a right angle (Fig. $3 \mathrm{C}$ ). The tentacles at the tips of the siphons are a little different from those of $L$. lutraria, and the two outer circles of small tentacles on the ventral siphon are lacking.

\section{IDENTIFICATION OF ADULTS}

Identification of Lutraria magna presents no problem, as it may at once be recognized by the longitudinally cleft first cardinal tooth in the right valve, the more acute angle between the two cardinal teeth, the absence of posterior lateral teeth in both valves, and by the completely linear scar below the pallial sinus.

It is difficult to find a single character which will invariably separate L. angustior from L. lutraria. Where the periostracum is intact, the presence 
of fine radial striae in the older parts of the shell (not to be confused with wrinkling in the later brown periostracum) is a sure recognition character for L. lutraria. The longitudinal grooving of the inner dorsal surface in L. lutraria and the shape of the pallial scars, although showing some degree of variation, are also valuable characters. The degree of curvature of the first cardinal tooth in the right valve, the angle between the teeth in this valve, and the outline of the shell are all rather variable, and should only be used in combination with the more diagnostic characters noted above. Additional characters are the more pointed umbo of L. lutraria, and the greater thickness of the shell in L. angustior.

\section{IDENTIFICATION OF YOUNG STAGES}

I have not examined small specimens of L. magna, but this species should be readily identifiable at all sizes from hinge characters, particularly the form of the first cardinal tooth in the right valve.

$\mathrm{Mr}$ Ford's collection contains small shells (length range 3-22 $\mathrm{mm}$ ) of L. lutraria and of another form (labelled L. magna) from shell-gravel deposits in Plymouth Sound. The latter appears to be L. angustior.

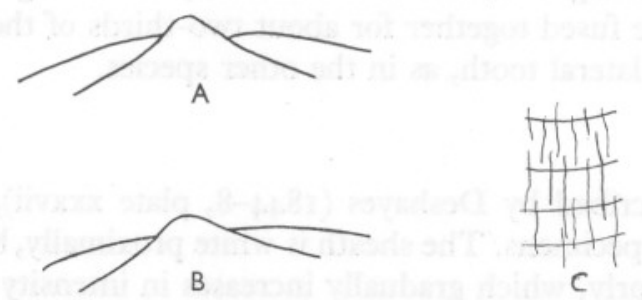

Fig. 4. Identification of young stages. A, lateral view of umbo and dorsal side of left valve of $L$. lutraria (4-5 mm long); B, similar view of $L$. angustior; C, radial markings on periostracum of L. lutraria.

At these sizes the shells are white, glossy, and translucent. Comparison of the two species shows that some of the specific differences between the adults are of no use in identifying the young stages. For example, the pallial line is difficult or impossible to distinguish at this stage. While the hinge of small L. lutraria is similar to that of the adult, that of L. angustior differs in that the two cardinal teeth diverge at almost a right angle, and the inner dorsal surfaces of the shell are grooved as in L. lutraria. The form of the cardinal teeth is explained by the fact that the first tooth in the right valve is curved in the adult, and actually diverges from the second at nearly a right angle, so that the angle between the teeth in a young shell would be greater than in the adult. The grooving of the inner dorsal surfaces is discussed in the next section. 
The two species may, however, be distinguished by:

(i) The shape of the beak, which is more acute in L. lutraria (Fig. 4A, B).

(ii) The presence of irregular radial striae in the periostracum of $L$. lutraria (Fig. 4C), these being absent in L. angustior.

\section{STATUS OF L. ANGUSTIOR}

It is evident that L. magna is a species quite distinct from the other two, the question at issue being whether L. angustior is a variety of L. lutraria or a separate species.

Since $L$. angustior inhabits shell gravel while $L$. lutraria inhabits muddy sand, some of the differences between them might be attributed to environmental influences. The looser and possibly more disturbed substratum inhabited by $L$. angustior may require a greater degree of burrowing activity, which might be shown, for example, in a shell which was relatively narrower than in L. lutraria. Greater activity might also affect growth of the shell along the inner dorsal surface, so producing a convex rather than a concave surface in larger specimens. However other differences remain, notably the presence of fine radial markings in L. lutraria, the angle between the cardinal teeth, the form of the pallial scar, and the colour and degree of separation of the siphons, which cannot readily be attributed to environmental effects.

In spite of a certain variability of some characters there appears to be no intergrading between the two forms, and it therefore seems reasonable to infer that $L$. angustior is a separate species, the name being taken from Philippi's (1844) description of a variety of Lutraria elliptica from Sicily.

I am indebted to $\mathrm{Mr} \mathrm{A}$. W. Battin for assistance with some of the drawings, and to Mrs E. A. Peace for taking the photographs for Plates I and II. Much of the material was obtained by the Plymouth Laboratory's research vessels, and I am grateful to their captains and crews for their assistance in making these collections.

\section{Note added in proof}

Through the kindness of Dr H. A. Rehder of the U.S. National Museum, Washington, I have received photographs of a pair of valves of $L$. elliptica var. alterutra from the Jeffreys collection. These leave no doubt as to the identity of Jeffrey's variety with the species L. augustior described here. Details of locality are lacking, and this lectotype has been recatalogued under the reference USNM Cat. No. 622510.

Dr R. Kilias of the Zoologisches Museum der Humboldt-Universität, Berlin, has kindly loaned me a pair of valves of an adult specimen labelled 'Lutraria elliptica var. augustior Phil. Sicilien. Benoit. 6223'. These are of particular value as they come from the same country as Philippi's specimens. The shell material is a little thinner and is less abraded than in the British 
specimens, suggesting that the habitat was more sheltered from wave or current disturbance. The shells agree with the description of L. angustior given in this paper in most particulars, and since the periostracum is intact it is possible to see that the fine radial markings on the outer surface are absent, so confirming that the specimens are not $L$. lutraria. The only significant difference is in the dorsal edges, which are slightly produced upwards and inwards so that the inner surfaces are slightly concave. The longitudinal grooves so formed are not as deep as in L. lutraria however, and this upward extension of the shell is no doubt the normal condition when living in more tranquil conditions.

\section{SUMMARY}

Two species of the genus Lutraria, L. lutraria (L.) and L. magna (da Costa) are well known in British waters. To these is added a third, originally described as L. elliptica var. angustior by Philippi, but which is considered sufficiently distinct to merit specific rank. A description of the third species, to be called L. angustior Philippi, is given, and differences between it and the other two species described. Small specimens taken by Mr Ford in Plymouth Sound and identified as L. magna are considered to be L. angustior, so that there are at present no records of L. magna from the Plymouth area.

\section{REFERENCES}

BRown, T., 1827. Illustrations of the Conchology of Great Britain and Ireland. 52 plates. London.

- 1844. Illustrations of the Recent Conchology of Great Britain and Ireland, with the Descriptions and Localities of all the Species, Marine, Land and Fresh Water. 2nd edition. I44 pp. London.

Bucquoy, E., Dautzenberg, P. \& Dollfus, G., I896. Les Mollusques Marins du Roussillon. Tome II. Fasc. XXIV, pp. 54I-620. Paris.

Deshayes, M. G. P., I844-48. Histoire Naturelle des Mollusques. Tome I. Mollusques Acéphalés. Exploration scientifique de l'Algerie pendant les années I840, I84I, I842. Texte $609 \mathrm{pp}$, Atlas, I6o pp.

ForD, E., I923. Animal communities of the level sea-bottom in the waters adjacent to Plymouth. F. mar. biol. Ass., U.K., Vol. 13, pp. 164-224.

- 1925. On the growth of some lamellibranchs in relation to the food supply of fishes. F. mar. biol. Ass., U.K., Vol. 13, pp. 531-59.

Hidalgo, J. H., I870. Moluscos Marinos de España, Portugal y las Baleares. Tomo III and Tomo IV (Atlas).

Holme, N. A., 1950. The bottom fauna of Great West Bay. F. mar. biol. Ass., U.K., Vol. 29, pp. I63-83.

JefFreys, J. G., I863. British Conchology. Vol. II, 466 pp. London.

Monterosato, Marchese DI, I878. Enumerazione e sinonima delle Conchiglie Mediterraneo. G. Sci. nat. econ. Palermo, Vol. 13, pp. 6I-II5.

PhILIPPI, R. A., I844. Enumeratio Molluscorum Siciliae cum Viventum Tum in Tellure Tertiaria Fossilium. Vol. 2, 303 pp. Halle.

Sowerby, G. B., I859. Illustrated Index of British Shells. Ist edition. London.

Turton, W., 1819. A Conchological Dictionary of the British Isles, 272 pp. London. 


\section{APPENDIX \\ RECORDS OF L. ANGUSTIOR}

Philippi's type locality is in Sicily, and Bucquoy et al. (I896) record it from the beaches of La Franqui and Leucate. Records from British waters attributed to this species are to be found in Turton (I8I9), Brown (I827, I844) and Jeffreys (I863).

Localities from which I have recorded L. angustior are as follows:

St Austell Bay, Cornwall

$50^{\circ} \mathrm{I} 8 \cdot 7^{\prime} \mathrm{N}, 04^{\circ} 44 \cdot 8^{\prime} \mathrm{W}$. Muddy gravel, II m. One small living specimen. $16 / 11 / 50$.

$50^{\circ} 19 \cdot 9^{\prime} \mathrm{N}, 04^{\circ} 43 \cdot 8^{\prime} \mathrm{W}$. Lithothamnion gravel, $9 \mathrm{~m}$. One small living specimen. I6/II/50.

\section{Plymouth area}

Eddystone Amphioxus shell gravel. Occasional living specimens; siphons and dead shells often taken. $42-47 \cdot 5 \mathrm{~m}$.

Mewstone shell gravel. Dead shells and siphons. ca. $27 \mathrm{~m}$. March, I959.

Plymouth Sound. Living specimens at several stations in shell gravel.

See Ford (1923, as L. magna).

Great West Bay

Station 6 (see Holme, I950). Muddy sand and gravel, $19 \mathrm{~m}$. One small living specimen (listed as L. lutraria). 29/7/48.

\section{Dawlish Warren}

A pair of valves (? living) washed up on beach. 3/2/50.

\section{Weymouth Bay}

$50^{\circ} 36 \cdot 95^{\prime} \mathrm{N}, 02{ }^{\circ} 22 \cdot 9^{\prime} \mathrm{W}$. $18 \mathrm{~m}$. Dead shells. II $/ \mathrm{II} / 58.50^{\circ} 37^{\circ} 0^{\prime} \mathrm{N}$, $02^{\circ} 20 \cdot 6^{\prime} \mathrm{W}$. I8 m. Dead shells. II $/ \mathrm{II} / 58$. $50^{\circ} 36 \cdot 4^{\prime} \mathrm{N}, 02^{\circ}$ I9 $75^{\prime} \mathrm{W}$. I9 m. Dead shell. II $/ \mathrm{II} / 58$. $50^{\circ} 34 \cdot 6^{\prime} \mathrm{N}, 02^{\circ} \mathrm{I} 4 \cdot 45^{\prime} \mathrm{W} .27 \mathrm{~m}$. Dead shell. II $/$ I I $/ 58$. $50^{\circ} 34 \cdot 0^{\prime} \mathrm{N}, 02^{\circ} 08 \cdot 7^{\prime} \mathrm{W}$. $26 \mathrm{~m}$. Dead shell. II $/$ II $/ 58$.

\section{Swanage Bay}

$50^{\circ} 37 \cdot 65^{\prime} \mathrm{N}$, or ${ }^{\circ} 53 \cdot 7^{\prime}$ W. ca. 18 m. Dead shells. 28/1/59.

\section{Torbay}

Additional records, added in proof

Several, living, washed up at Three Beaches, Goodrington after E. gale. $3 / 4 / 58$. 
Falmouth Bay

One small living specimen at each of two stations:

$50^{\circ} 06 \cdot 65^{\prime} \mathrm{N}, 05^{\circ} 03 \cdot 4^{\prime} \mathrm{W}$. ca. $18 \mathrm{~m}$. Lithothammion gravel. 17/7/59.

$50^{\circ} 07 \cdot 2^{\prime} \mathrm{N}, 05^{\circ} 04 \cdot 3^{\prime} \mathrm{W}$. ca. $37 \mathrm{~m}$. Lithothammion gravel. 17/7/59.

\section{Mount's Bay}

One small living specimen at:

$50^{\circ} 06 \cdot 3^{\prime} \mathrm{N}, 05^{\circ} 30 \cdot 3^{\prime} \mathrm{W}$. ca. $22 \mathrm{~m}$. Gravel and stones. 16/7/59.

\section{EXPLANATION OF PLATES}

\section{PLATE I. Lutraria angustior}

Fig. I. Interior of right valve. Dead shell, Swanage Bay. $\times 1 \cdot 2$.

Fig. 2. View with foot and siphons moderately extended. Eddystone shell-gravel. $\times 0.65$. Fig. 3. Dorsal view. Eddystone shell-gravel. $\times 0 \cdot 75$.

\section{Plate II}

Fig. I. L. lutraria. Interior of right valve. From a living specimen. Millport. About natural size.

Figs. 2, 3. L. lutraria. Hinges of left and right valves. Note the accessory tooth, often broken off, in the left valve behind the 2nd cardinal tooth. From living specimens. Millport. $\times c a .1 \frac{1}{3}$.

Figs. 4,5 . L angustior. Hinges of left and right valves. Dead shells. Swanage Bay. $\times c a .1 \frac{1}{3}$. Fig. 6. L. lutraria. Posterior part of shell, and partially extended siphons. The dorsal side is uppermost. Cornwall. $\times 0.87$. 

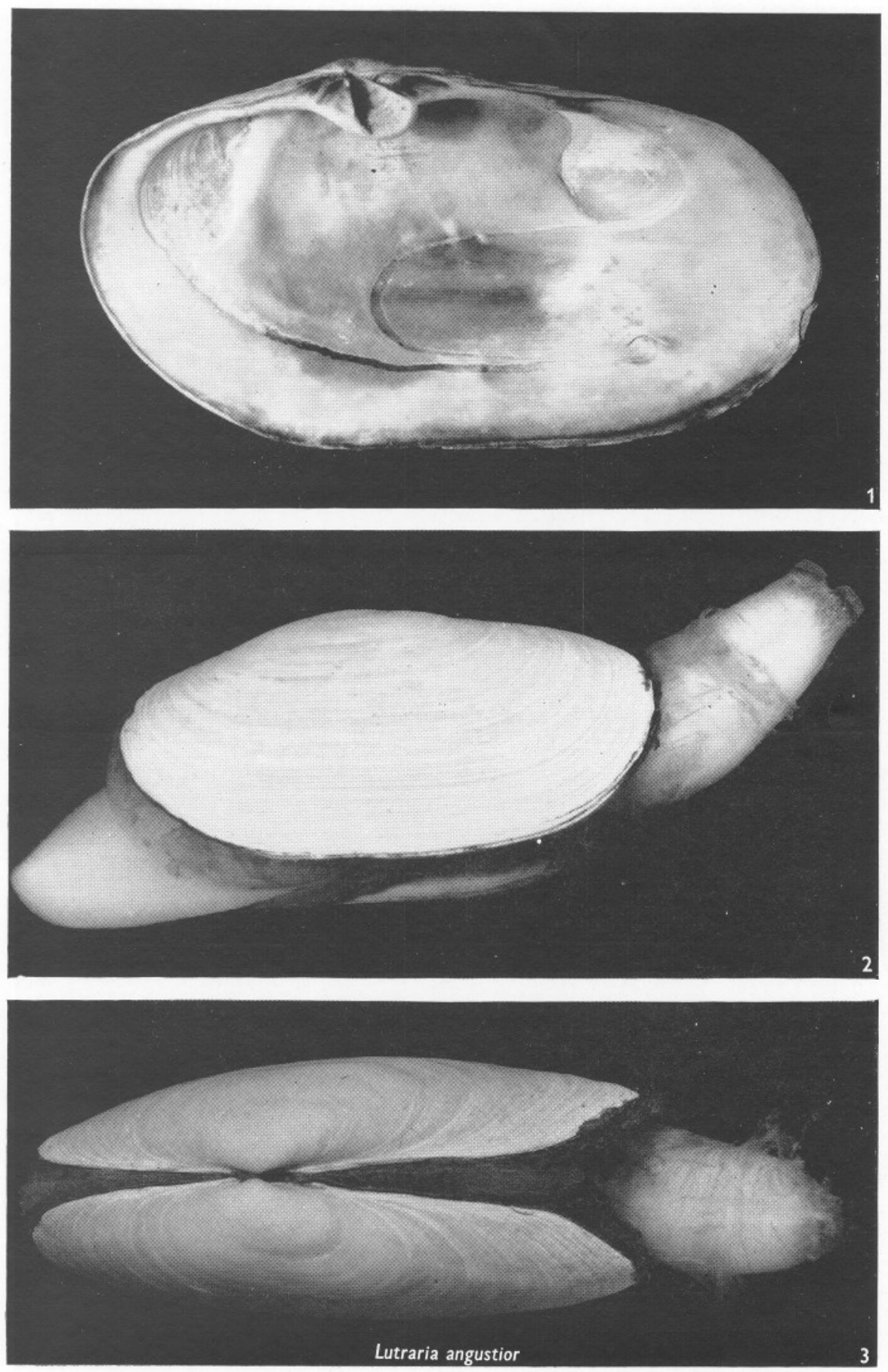

(Facing p. 568) 

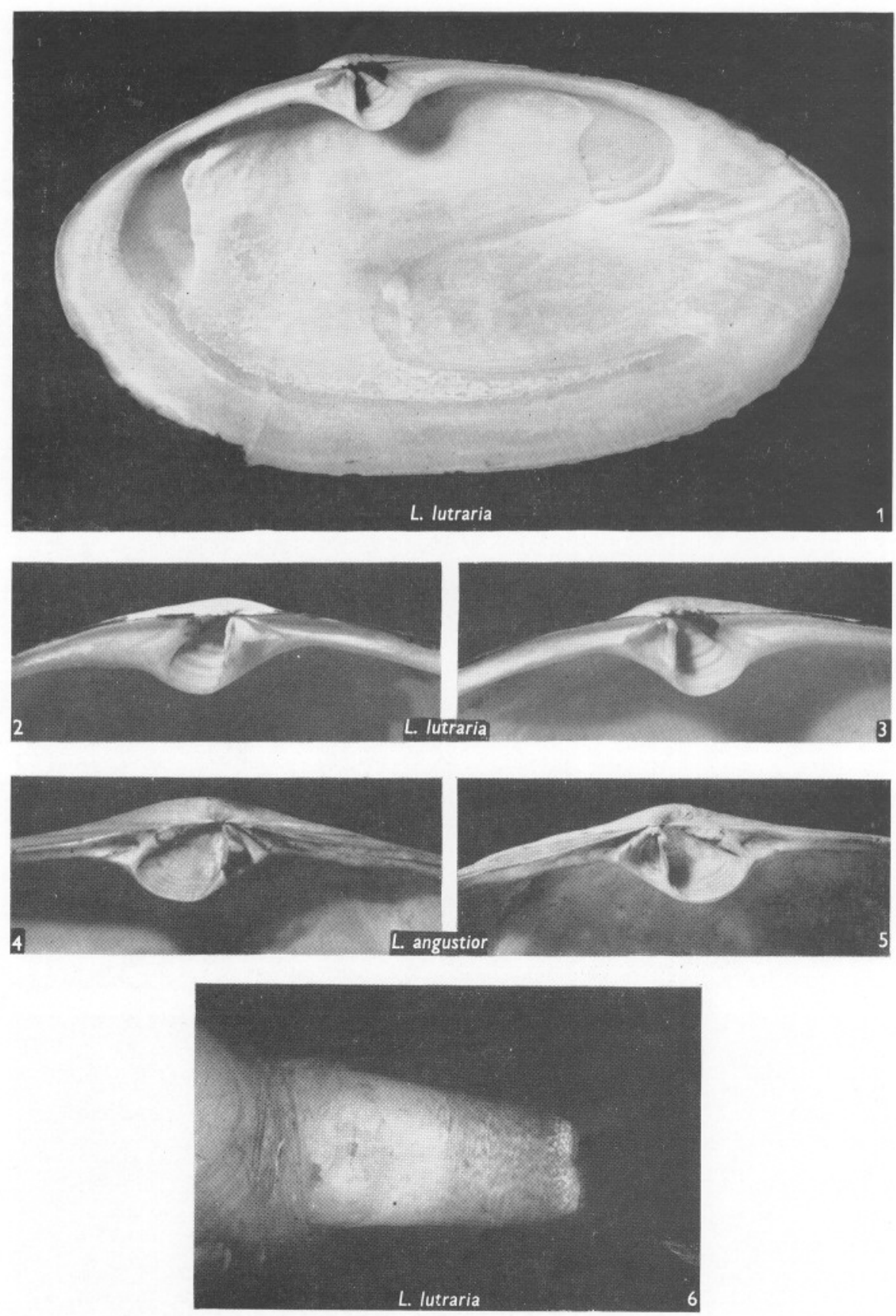